\title{
TÖMÖRÍTÉSI EGYÜTTHATÓ BEFOLYÁSA A HÁROMTENGELYÜ GEORÁCSOKKAL MEGERŐSÍTETT ÚTSZERKEZETEK TARTÓKÉPESSÉGÉRE
}

\section{INFLUENCE OF THE DEGREE OF COMPACTION ON THE BEARING CAPACITY OF A ROAD STRUCTURE REINFORCED WITH TRIAXIAL GEOGRIDS}

\author{
Nagy Andor-Csongor, ${ }^{1}$ Hajdó Harmat, ${ }^{2}$ Kis Ádám, ${ }^{3}$ Moldovan Dorin-Vasile ${ }^{4}$ \\ Kolozsvári Müszaki Egyetem, Epitőmérnöki kar, Tartószerkezet tanszék, Kolozsvár, Románia \\ 1 andor.nagy@yahoo.com \\ ${ }^{2}$ harmat.hajdo@gmail.com \\ 317sadam@gmail.com
}

\begin{abstract}
The degree of compaction for a crashed stone roadbed is one of the most important technical characteristic in road construction works. An insufficient compaction can have significant effects on the resulting bearing capacity, even if the road structure is reinforced with geosynthetic mate-rials. The present study concernes the utility of using geosynthetic reinforcement in the base layer of a road structure, while varying the degree of compaction on 1:1 scale models.
\end{abstract}

Keywords: triaxial geogrid, degree of compaction, bearing capacity of a road structure.

\section{Összefoglalás}

A tömörítési együttható meghatározó műszaki jellemzője az útépítési munkálatoknak. Egy sikertelen tömörítésnek számos olyan hatása van, amely befolyásolja az adott talajszerkezet így kapott teherbíró képességét, még geoszintetikus anyagokkal megerősített töltések esetében is. A tanulmány megvizsgálta a geoszintetikus megerősítésnek az úttöltés alaprétegébe történő elhelyezésének hasznosságát, mindezt a teherbíró képesség vizsgálatával, georács-megerősítéssel, valamint geoszintetikus anyag nélkül, variálva a különböző tömörítési fokokat.

Kulcsszavak: háromtengelyü georácsok, tömörítési együttható, útszerkezetek tartóképessége.

\section{Bevezetés.}

A jelenlegi kutatás kéttípusú 1:1 méretarányú modell fejlesztését foglalta magában. Az egyik egy közúti töltés, amelynek alaprétegét megerősítettük egy triaxiális georáccsal, valamint egy geoszintézis nélküli modellt hoztunk létre. A tanulmányozott szerkezeti modellt egy dobozban valosítottuk meg, amelynek a következőek a tér- beli méretei: $(\mathrm{b} \times \mathrm{L} \times \mathrm{h}) 1,50 \times 2,00 \times 1,00 \mathrm{~m}$, létrehozva a hosszanti nyitással (L) középen egy kihúzható fiókot, amelynek a következőek a méretei: $0,50 \times 1,70 \times 0,25 \mathrm{~m}$, ahogy mindez 1 . ábrán is szemléltetve van.

A fiók eltávolítását követően a vizsgált talajszerkezetet kb. 20 órán át állni hagytuk, amely idő alatt a saját súlya alatt konszolidálódott. Ezt a folyamatot a további kísérletek során is beiktattuk. 


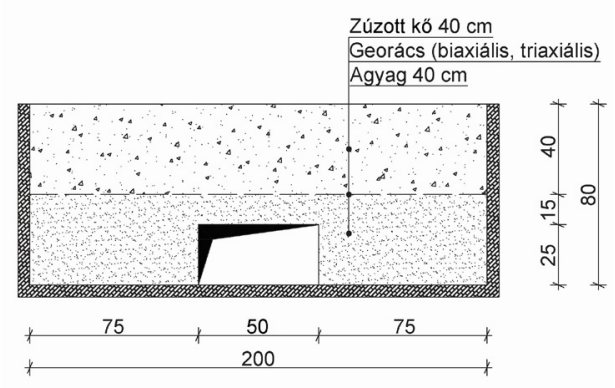

1. ábra. A használt útszerkezet vázlata (a megerősítetlen modell esetében a georácsot elhagyták)

A kísérletek folyamán használt georács típusa TriAx TX140, 40 mm-es háromszögnyílásokkal, illetve a radiális merevségének mértéke $225 \mathrm{kN} / \mathrm{m}$.

Az alsó réteg agyagos növényi talajból, míg a létrehozott közúti alapréteg 0-63-as optimális keverésű zúzott kőből áll. Mindkét réteg $40 \mathrm{~cm}$ vastagságú.

A teherbíró képesség megállapítására használt kísérleti eszköz a Lucas-lemez volt, a kísérlet folyamán a modell statikus terhelését a létrehozott hézag irányába hajtottuk végre, amíg a vizsgált talajszerkezet beomlott. A kísérlet folyamán megfigyeltük a rés deformációit, a használt triaxiális georács csomópontjának eltolódását, amelyek a rés közepén helyezkedtek el, illetve annak szélein.

\section{A modellek megvalósítása}

A tömörítés a GE-026-97 [1] előírásoknak megfelelően történt. Az optimális tömörítési értéket laboratóriumi körülmények közt, normál Proctorteszt segítségével határoztuk meg, úgy, hogy a zúzott kő felső rétegének kiszámítottuk a száraz térfogatsűrűségét (“vizes zacskós módszerrel”, a STAS 1913-15/75 [2] előírásoknak megfelelően), összehasonlítva azt a vizsgált talaj száraz maximális térfogatsűrűségével, mindezt optimális nedvességtartalommal összemérve. A geoszintetikus rács nélküli, valamint az első megerősített modell esetében megfelelő tömörítési eljárást alkalmaztunk, vagyis a két réteget két szakaszban tömörítettük (mindegyik réteget 20 cm-es vastagságúra), többszörös áthaladással, és legalább 4 ütést applikálva mindegyik nyomra. A második megerősített modellben a zúzottkő-réteg nem megfelelően volt tömörítve, mindössze 2 sorozattal, és ennek hatására csak 81\%-os tömörítési együtthatót értünk el ennél a modellnél. Összehasonlítva mindezt az előző modellekhez képest, a különbség számottevő (93-95\% - az előző két modell alkalmával).

\section{A teherbíró képesség vizsgálatának folyamata}

\subsection{Triaxiális georáccsal megerősített modell - optimális tömörítés}

Az első kísérlet alkalmával a teherbíró képesség megállapítása egy triaxiális georáccsal megerősített szerkezeti modellen volt alkalmazva, megfelelő tömörítési együttható alkalmazásával. A statikus terhelés Lucas-lemez felhasználásával valósult meg, amelynek átmérője $300 \mathrm{~mm}$, központi elhelyezkedésü, vagyis a fiók által kialakított hézagra helyezve. A terhelési lépések a STAS 2914/4-89 [3] előírásainak felelnek meg, pontosabban a közúti szerkezeti rendszereknek megfelelően egy $50 \mathrm{kPa}$-os terhelésnövekedéssel, 0.05 mm-es stabilizációs határértékkel, 5 percenként egy-egy mérést követően. Ezt a tesztet addig végeztük, amíg a kísérleti modell szerkezete beomlott [4]. Az első kísérlet alkalmával feljegyzett süllyedések a következőek: $1 \mathrm{~mm} 100 \mathrm{kPa}$ alkalmazásával, $1.5 \mathrm{~mm} 150 \mathrm{kPa}$ terhelés alatt, valamint $3 \mathrm{~mm} 200 \mathrm{kPa}$ terhelés alatt . Az első üreg körüli észrevehető deformáció 10 perc utáni 200 $\mathrm{kPa}$-os terhelést követően volt megfigyelhető, az üreg mennyezete $2 \mathrm{~mm}$ deformálódott. A tanulmányozott szerkezet konszolidációs ideje gyors volt, 15 perc az $50 \mathrm{kPa}$-os terhelési lépésben, 15 perc a $100 \mathrm{kPa}$-os terhelés alkalmával, 20 perc a $150 \mathrm{kPa}-$ os terhelés alkalmával, valamint 15 perc a $200 \mathrm{kPa}$-os terhelési lépésben. A $250 \mathrm{kPa}-\mathrm{os}$ terhelési lépés alkalmával történt az első közepes méretű földdarabka lehullása (2. ábra).

Megállapítottuk, hogy a teljes deformációnak nem volt jelentős növekedése, a 25 perc eltelte utáni mérés $4 \mathrm{~mm}$ nagyságú elváltozást mutatott. A fejlődés hasonló volt a következő terhelési lépésben is, $300 \mathrm{kPa}$ terhelés alatt, továbbra is meg-

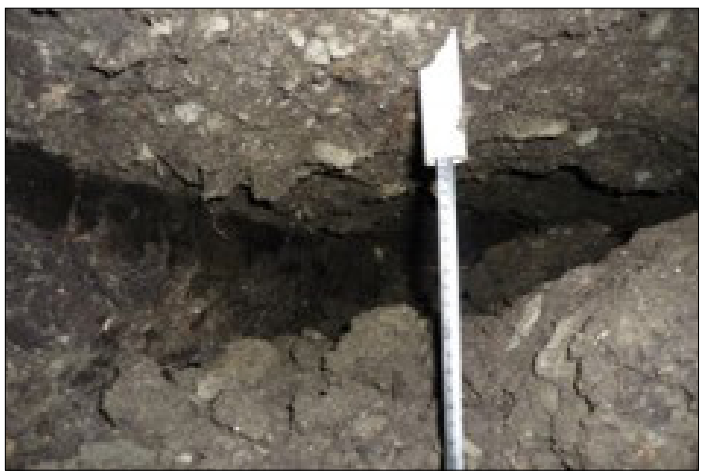

2. ábra. Statikus terhelések következtében az üreg összeomlik 
figyelhető volt a földdarabkák fokozatos leomlása, valamint a stabilizációs határértéket kb. 20 perc elteltével értük el, 5,5 mm-es elváltozással.

A 350 kPa-os terhelés alatt az üreg felső részének nagy felülete beomlott. Egyidejüleg megfigyelhettük a kitöltési ív létrejöttét, amely eloszlatta az üreg közepére mért nyomást az oldalfalak területére. A megerősített szerkezet viselkedésén $400 \mathrm{kPa}$-os terhelés mellett észrevettük, hogy a deformációk csak 25 perc után stabilizálódtak. A vizsgált szerkezet gyorsan konszolidálódott a $450 \mathrm{kPa}$-os terhelés alatt, 20 perc után mérhető volt a deformáció $3 \mathrm{~mm}$-es növekedése (7,0 mm ről 7,3 mm-re). Még az 500 kPa-os terhelési fokra való átváltás sem okozott jelentős deformációkat, az elmozdulások kezdetben $1 \mathrm{~mm}$-t mutattak, majd a vizsgált talajszerkezet stabilizálódásának alkalmával (35 perc terhelést követően) az összelmozdulás értéke $5 \mathrm{~mm}$ volt $(8,0 \mathrm{~mm}$-ről 8,5 mm-re). A triaxiális georáccsal megerősített vizsgált talajszerkezet az $550 \mathrm{kPa}$-os terhelés hatására nagyobb, mint 10 mm-es deformációkat szenvedett el. A konszolidációs időtartamok állandóságát a következő két terhelési szakaszban is megőriztük, 600, valamint $650 \mathrm{kPa}$ terhelés alatt, mindezt 45 perc elteltével. A közúti szerkezet viszonylag keveset deformálódott, $600 \mathrm{kPa}$ terhelés következtében leolvashattunk egy 12,2 mm nagyságú középértéket, valamint 15 mm-t a 650 kPa-os terhelés alkalmával. A zúzottkő-réteg felületén a repedések $700 \mathrm{kPa}$ terhelés alatt jelentkeztek. A következő terhelési szakaszban $(750 \mathrm{kPa})$ egy 2 mm-es konstans értékủ elváltozás volt megfigyelhető olvasási intervallumonként. A 35 perces időintervallumban rögzítettük a belső csomópont első elmozdulását. Ebben a terhelési szakaszban az elmozdulás kissé megnőtt, 15 percet követően elérte a 6,5 mm-es értéket.

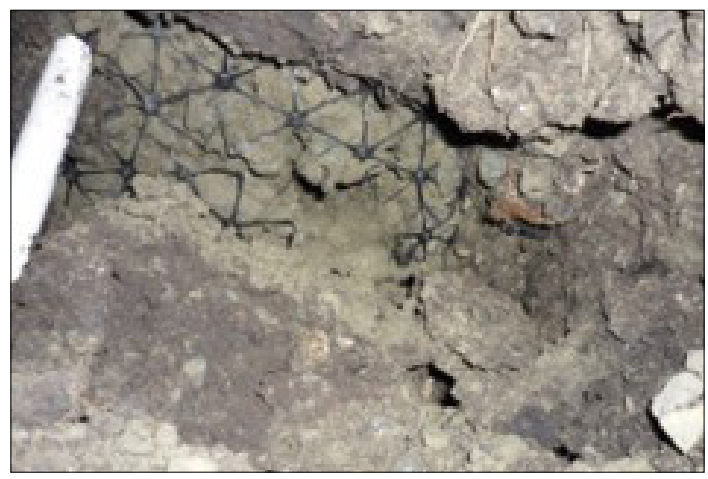

3. ábra. A föld összeomlása eredményeképpen a georács megrongálódik
A következőkben 800 kPa-os erőhatás következtében a vizsgált szerkezet 5 perc után összeomlott. Az üreg körüli földréteg összeomlását követően megfigyelhető volt, ahogy a zúzott kő megragad a georácshálóban, illetve ahogy a triaxiális georács elszakad (3. ábra).

A zúzottkő-réteg és a triaxiális georács eltávolítását követően megállpítható volt, hogy a repedés a nyomáskúp kerületének egy részén történt.

\subsection{Triaxiális georáccsal megerősített modell - sikertelen tömörítés}

Sikertelen tömörítés alkalmával (alacsony tömörítési együttható) a szerkezetnél megfigyelhettük, hogy a 200 kPa-os terhelés alatt a deformációk megnövekedtek, észrevehető már az első mérési lépés alkalmával, deformáció $211 \mathrm{~mm}$ az üreg központi részén, valamint $585 \mathrm{~mm}$ annak szélein. Jól érzékelhető deformációk mutatkoztak meg a 25 perc elteltével végrehajtott mérés alkalmával, számszerűsítve mindezt $210 \mathrm{~mm}$, azonban az üreg mennyezetének hosszirányú repedései is hangsúlyt kaptak. A földréteg ezen szintje alatt 40 percet követően megszilárdult, és a eltolódás csúcsértéke 5,5 mm volt. A következő terhelés alkalmával (250 kPa) az eltolódások láthtóan megugrottak, az üreg eldeformálódott, ezáltal létrehozva az üreg új 208 mm-es központi magasságát, valamint 586 mm-es szélein lévő magasságot. Formai és méretbeli változásokon ment át, elérve a 205 mm-es értéket 55 perc elteltével.

A vizsgált talajszerkezet konstans konszolidációs értékét 65 perc terhelés után kaptuk meg, az utolsó mérési intervallumban az elmozdulás értéke 10,5 mm volt. A 300 kPa mértékű terhelés felgyorsította az elmozdulást az első 20 percben, elérve a 3 mm különbségű elmozduláshoz az alsó terhelési lépcsőhöz képest, majd az elmozdulási értékek konstans módon kezdtek el növekedni, kb. hat tizedmilliméterrel. Ennek a terhelésnek az alkalmával az üreg mennyezete leereszkedett $5 \mathrm{~mm}$ - $\mathrm{t}$ az első mérési adatokhoz képest, és ez a tendencia arra engedett következtetni, hogy 40 perc elteltével a mérések 197 mm-t mutattak a központi elhelyezésű mérőrúdon, és összehasonlítva ezt az első mérési eredménnyel, $215 \mathrm{~mm}$, létrejött egy közel 20 mm-es deformáció. A deformáció továbbítódott az üreg teljes felületén, a mérőrúd ez alkalommal az üreg szélén elhelyezve 589, 590, valamint $591 \mathrm{~mm}$ mértékủ eredményeket mutatott. Tehát a mérőeszközön leolvasott deformációk mértéke konstans növekedést mutatott hat tizedmiliméter értékkel, a vizsgált talajszerkezet 100 
és 110 perc időintervallumban szilárdult meg. Az összelmozdulási érték kb. 22 mm volt.

Az utolsó terhelési lépésben alkalmazott erő, $350 \mathrm{kPa}$, hatására a szerkezet leomlása késleltetve volt az 5 perces időintervallum eléréséig (4. ábra). Ettől a ponttól a szerkezet alsó részének boltozathatása megszűnt, a deformációkat csak a georács megnyúlása vette át.

$\mathrm{Az}$ 5. ábrán megfigyelhető a zúzott kőnek a georácsba való beágyazása, valamint annak kitüremkedése a georács résein. Ettől a pillanattól kezdve az elmozdulások gyors növekedést mutattak, számszerüsítve $3 \mathrm{~mm} /$ perc, valamint az üreg falai összeomlottak.

A triaxiális georács belső csomópontja, fleximéterrel követve, $1 \mathrm{~mm}$-t mozdult el percenként. A $350 \mathrm{kPa}$-os terhelés hatására a georács 12 perc után bomlott meg. Az összeomlás pillanatában 51,6 mm-es elmozdulás volt mérhető a mérőlemez alatt. A törési kúp falai kb. 45 fokos szöget zártak a vízszintes iránnyal. A zúzottkő-réteg, valamint a georács eltávolítása után megmértük a törési kúp

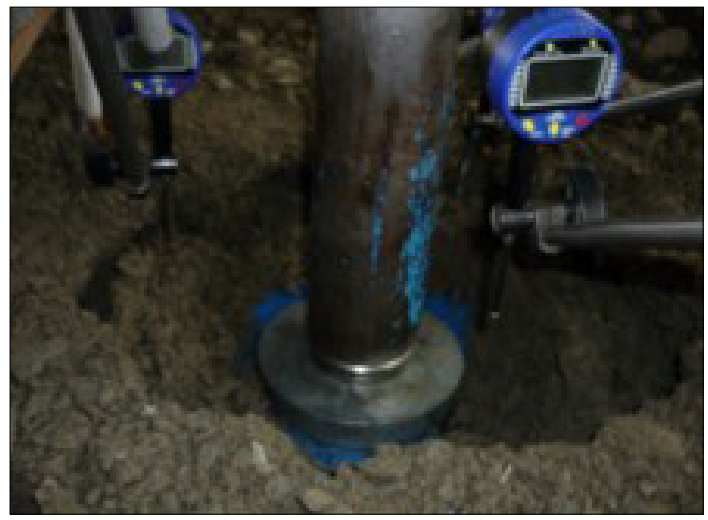

4. ábra. 350 kPa terhelés alatt összeomlik a szerkezet

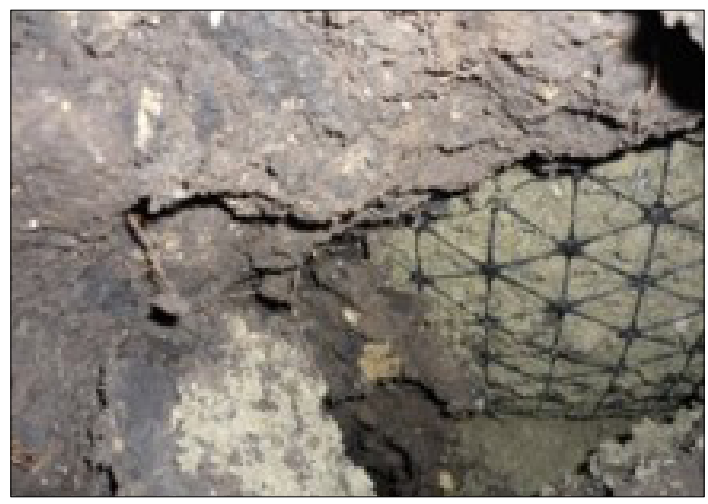

5. ábra. A szerkezet beomlása nyomán láthatóvá válik a beágyazás lenyomatát, amely $105 \mathrm{~cm}$ volt. A zúzottkő-réteg eltávolításának alkalmával felfedeztünk a georácson egy szakadási pontot (6. ábra), majd a teljes feltárást követően még két hasonló szakadási pont jelenlétét állapítottuk meg (7. ábra), a terhelési felülettel ellentétes oldalon.

Ez a jelenség kizárta a beágyazási folyamat jótékony hatását, és lehetővé tette a zúzottkő-réteg kisebb mértékű összeomlását az üregen belül, azonban a külső csomópontban már nem voltak mozgósítva a nyújtási erők a rácson belül, így ennek irányában az értéke nulla maradt.

\subsection{Geoszintetikus rács nélküli modell}

Ahhoz, hogy meg lehessen határozni a georácsos megerősítés hatásainak mértékét, egy harmadik megerősítés nélküli modellt is létrehoztunk, amely ez alkalommal georácsot nem tartalmazott.

$\mathrm{Az}$ szerkezet létrehozása a fentiekben hasonlóan történt, a fiók eltávolítását követően a vizsgált talajszerkezetet kb. 20 órán át állni hagytuk, amely idő alatt a saját súlya alatt megszilárdult. A georácsos szerkezetektől eltérően, ez a szerkezeti

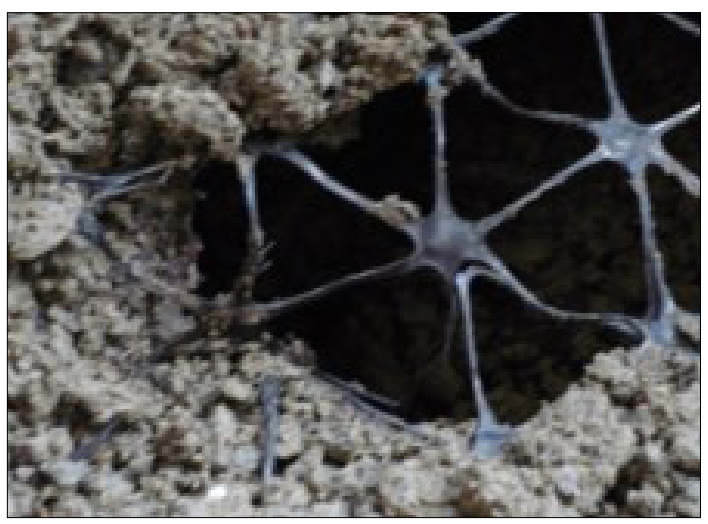

6. ábra. Omlás a triaxiális georács mentén

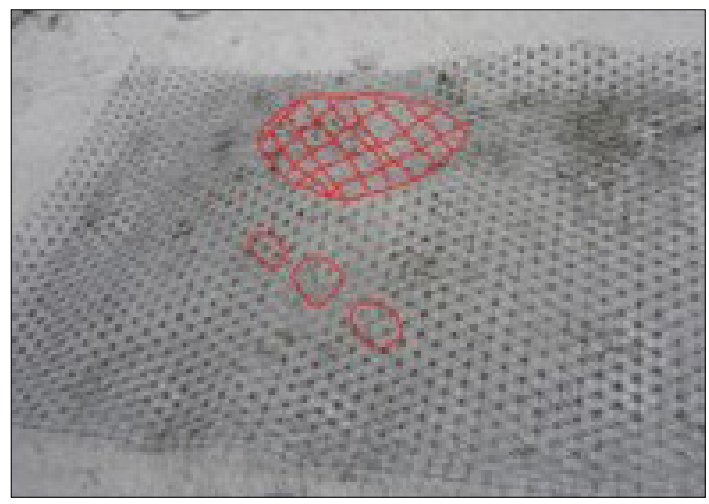

7. ábra. A nyomáskúp, valamint a három átlósan elhelyezkedő szakadási pont 
modell a saját súlya alatt történő konszolidáció következtében a lyuk közepére helyezett mérőrúd 24 óra után mutatott értéke $210 \mathrm{~mm}$ volt, öszszehasonlítva a kezdeti 215 mm-hez.

Az első terhelési szakaszt követően, $50 \mathrm{kPa}$ hatására nem következtek be jelentős deformációk a szerkezetben, az összelmozdulási érték két tized miliméter alatt voltak a konszolidáció pillanatában. A 100 kPa-os terhelési szakasz 10 percig tartott, amely két leolvasási ciklusnak felel meg, megadva a 0,6 mm-es elmozdulást a tesztlemez alatt. Az üreg központi része még a harmadik terhelési szakaszt követően sem szenvedett méretbeli változásokat $(150 \mathrm{kPa})$. Csak a 20 . percet követően lépett érvénybe egy $2 \mathrm{~mm}$ nagyságú elváltozás, amelyet az üreg szélén elhelyezett mérőrúdon olvashattunk le, amely jelezte a talajmozgást az üreg szélétől, hogy átvegye a terhelést a boltozathatáson keresztül. Az eredmény olvasásával egyidejűleg érvénybe lépett a vizsgált talaj konszolidációja, valamint továbbléptünk a következő terhelési szakaszba, 200 kPa értékkel. A 15 perc elteltével való eredményolvasás megmutatta az első deformációt, amely $2 \mathrm{~mm}$ volt. A mérőrúd az üreg szélén $2 \mathrm{~mm}$-t leereszkedett, elérve így az 577 mm-es értéket. A talaj konszolidációja 30 perc elteltével lépett érvénybe. A $250 \mathrm{kPa}$-os terhelési szakasz alkalmával kisebb méretű talajdarabkák omlottak le. Mivel a nyomás nem csökkent, ezért csak a tesztlemez alatt koncentrálódott az, így csak ott léptek érvénybe omlások. Az üreges mennyezet kisebb méretű talajdarabka-omlása mellett az oldalfalakban nem jöttek létre további repedések. Ez alatt a terhelési erő alatt a talaj 25 perc után érte el a konszolidációs küszöböt. A $300 \mathrm{kPa}$-os terhelésre való váltást követően meghatározható volt az olvasási ciklusonkénti 2 mm-es változási érték, az üreg mennyezetének a deformációja folytatódott, a központi elhelyezésű mérőrúd pedig $196 \mathrm{~mm}$-es értéket mutatott, a doboz aljától mérve. Az üreg szélén elhelyezve a mérőrudat, 579 mm-es mérhető érték volt, amely azt jelenti, hogy az üreg oldalsó falai is eldeformálódtak. Az összelmozdulás ebben a terhelési szakaszban elérte a 4,5 mm-es értéket 40 perc elteltével, amely 8 mérési ciklusnak felel meg. A következő terhelési szakaszban, $350 \mathrm{kPa}$, bekövetkezett az üreg mennyezetének beomlása a mérőrúd irányába (8. ábra).

Az elmozdulások kihangsúlyozódtak, az első mérést követően leolvashattunk egy 1,5 mm-es ugrást az alsó betöltési mérési lépéssel szemben. $\mathrm{Az}$ üreg továbbra is eldeformálódott, ez a tendencia különösen azért volt észrevehető, mert a

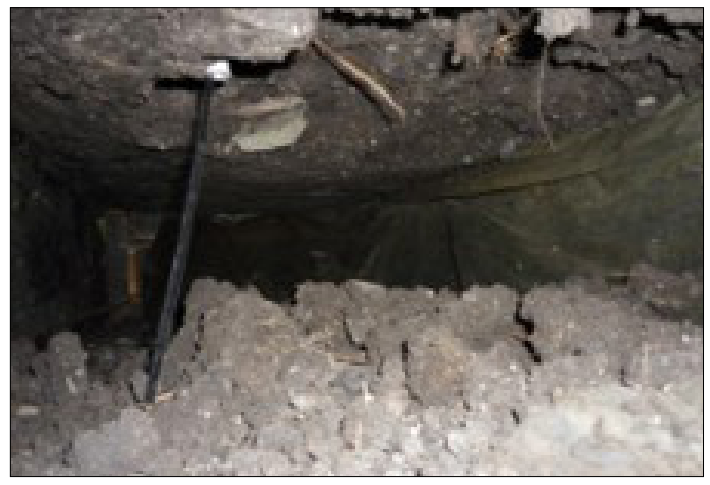

8. ábra. Az üreges mennyezetből származó nagyobb földdarabkák beomlanak a 350 kPa-os terhelés hatására

az üreg mennyezetének oldalsó részén kihangsúlyozódtak a repedések. Megjelentek az oldalsó falakon is kisebb beomlások, amelyet az üreg szélén lévő mérőrúd is jelzett. 45 perc elteltével mérhető volt a maximális elmozdulás, $7 \mathrm{~mm}$, lehetővé téve a leolvasások közötti különbséget, valamint a nagyobb terhelési fokra való váltást. A 400 kPa-os terhelés alkalmával az 1 cm-es deformációt is átléptük, az elmozdulások állandó növekedést mutattak, leolvasási intervallumonként kb. 0,2 mm-es értékkel. Ez alatt a terhelési lépés alatt a vizsgált talajszerkezet 65 perc után stabilizálódott. A következő terhelési szakaszban bekövetkezett közepes méretű földdarabkák leomlása, jelezve az összeomlás közeledtét. 35 percet követően 450 kPa-os terhelés kíséretében megmértük az üreges mennyezet deformációját, amelynek mértéke $1 \mathrm{~cm}$ volt, amely megfelel a tesztpanel mikrokomparatív óráin mért kalibrációnak. Geoszintetikus megerősítés nélkül elmondhatjuk, hogy a törtkő rétegrésze egyidejüleg deformálódik el a vizsgált talajjal. A talajkonszolidációt 40 perc alatt, $450 \mathrm{kPa}$-os terhelés alatt regisztráltuk. A következő terhelés további omlásokat eredményezett. Az üreg deformációja 20 és 90 perces időközönként regisztráltuk, a központi elhelyezésű mérőrúdon leolvasható értékek pedig $187 \mathrm{~mm}$, valamint $183 \mathrm{~mm}$ voltak. 110 perc után rögzítettük az elmozdulási értékeket, amelyek a talaj szilárdulását eredményezték, egy $3 \mathrm{~cm}$-es deformáció kíséretében. A következő terhelési szakaszban, 550 kPa-os terhelés hatására megvalósult a föld beomlása az üregbe (9. ábra), a deformációk kihangsúlyozódtak, $3 \mathrm{~cm}$-ről elérve egy $5 \mathrm{~cm}$-es értéket, mindezt 5 perc alatt, amelyet követően a tesztlemez elsüllyedt a saját súlya alatt és a hidraulikus emelő nyomására. 


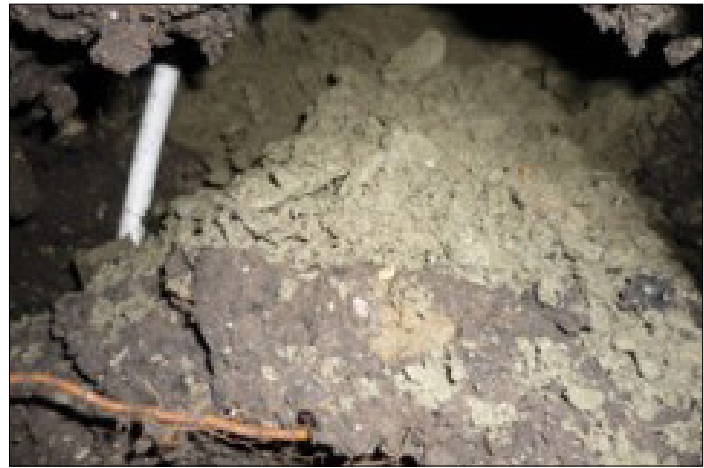

9. ábra. Az üreg összeomlott az 550 kPa-os terhelési nyomás alatt

Tekintettel arra, hogy a deformációk megengedett értékeinek elérése rövid volt, elmodhatjuk, hogy a létrejött összeomlás hirtelen jellegű volt. A törtkő felső rétegének egy része átfolyt a szerkezetben eredetileg kialakított üregbe. Az öszszeomlást követően kialakult kúp átmérője $45 \mathrm{~cm}$. A törtkő-réteg eltávolítását követően megfigyelhető volt az így létrejött kúp alsó részének alakja, valamint méretei mérhetőek voltak: $120 \mathrm{~cm}$ hoszszú, 85 cm széles. Az összeomlott felület megerősítette a kezdeti feltételezéseinket, miszerint ez csak egy lokális beomlás.

1. táblázat. Terhelési szintek értelmezése a teherbírás mértéke alapján

\begin{tabular}{|c|c|c|c|}
\hline $\begin{array}{l}\text { Terhelési } \\
\text { lépés }\end{array}$ & $\begin{array}{c}\text { Ekvivalens } \\
\text { koncentrált } \\
\text { erő }\end{array}$ & $\begin{array}{l}\text { Nyomás } \\
\text { érték }\end{array}$ & $\begin{array}{c}\text { Lemez } \\
\text { alatti } \\
\text { nyomás }\end{array}$ \\
\hline$[\mathrm{kPa}]$ & {$[\mathrm{kN}]$} & {$[\mathrm{tf}] / \mathrm{m}^{2}$} & [tf] \\
\hline 50 & 3,55 & 5,100 & 0,362 \\
\hline 100 & 7,10 & 10,200 & 0,724 \\
\hline 150 & 10,65 & 15,300 & 1,086 \\
\hline 200 & 14,20 & 20,400 & 1,448 \\
\hline 250 & 17,76 & 25,500 & 1,811 \\
\hline 300 & 21,31 & 30,600 & 2,173 \\
\hline 350 & 24,86 & 35,700 & 2,535 \\
\hline 400 & 28,41 & 40,800 & 2,897 \\
\hline 450 & 31,96 & 45,900 & 3,259 \\
\hline 500 & 35,51 & 51,000 & 3,621 \\
\hline 550 & 39,06 & 56,100 & 3,983 \\
\hline 600 & 42,61 & 61,200 & 4,345 \\
\hline 650 & 46,16 & 66,300 & 4,707 \\
\hline 700 & 49,71 & 71,400 & 5,069 \\
\hline 750 & 53,27 & 76,500 & 5,432 \\
\hline 800 & 56,82 & 81,600 & 5,794 \\
\hline
\end{tabular}

\section{Következtetések}

Az általunk tanulmányozott talajszerkezetek teherbírása tehát kifejezhető a következőképpen: $1 \mathrm{kPa}=101,972 \mathrm{kgf} / \mathrm{m}^{2}=0,102 \mathrm{tf} / \mathrm{m}^{2}$.

A kísérletben használt tesztlemez felülete $\phi 300 \mathrm{~mm}$, amely négyzetméterben kifejezve 0,071 $\left(0,071 \mathrm{~m}^{2}\right)$, mindez számszerüleg nagyon közel áll a forgalmi terhek kiszámításához használt kéttengelyü lemezlenyomathoz.

A gyengén tömörített szerkezet alacsonyabb terhelési értéket adott, mint a megerősítés nélküli szerkezet. A különbség a két átviteli lépés között 36\%-os volt (350 kPa şi $550 \mathrm{kPa}$ ). Összehasonlítva a $800 \mathrm{kPa}$-os értéket, hasonló talajszerkezeti esetet vizsgálva, viszont megfelelően tömörítve azt, a különbség számottevőbb, vagyis 56\%-os, és a teherbírás tényleges értéke több mint a duplájára nőtt.

Ezek az eredmények arra engednek következtetni, hogy a georács használata hiábavaló abban az esetben, ha az útrétegek megfelelő tömörítési foka nem valósul meg előzetesen [5, 6, 7, 8].

\section{Szakirodalmi hivatkozások}

[1] GE-026-97. Ghid pentru execuţia compactării în plan orizontal şi înclinat a terasamentelor

[2] STAS 1913-15/75. Teren de fundare. Determinarea greutăţii volumice pe teren.

[3] STAS 2914/4-89. Teren de fundare. Determinarea modulului de deformaţie liniară prin încercări pe teren cu placa.

[4] Moldovan D. V., Nagy A. Cs., Muntean L. E., Fărcaş V. S., Coţ R.: A comparative study of the failure mode of conventional road structures and of road structures reinforced with polypropylene rectangular mesh geogrids. $14^{\text {th }}$ International Multidisciplinary Scientific Geoconference SGEM2014, Albena, Bulgaria, 11-15.

[5] Agaiby Sherif W., Jones Colin J. F. P.: Design of reinforced fill systems to support footings overlying cavities. Geotextiles and Geomembranes, 14. (1996) 57-72.

[6] Asakereh A., Ghazavin M., Tafreshi S. N. Moghaddas: Cyclic response of footing on geogrid-reinforced sand with void. Soils and Foundations, 53/3. (2013) 363-374.

[7] Briançon L., Villard P.: Design of geosynthetic-reinforced platforms spanning localized sinkholes. Geotextiles and Geomembranes, 26. (2008) 416-428.

[8] Giroud J. P., Bonaparte R., Beech J. F., Gross B. A.: Design of soil layer-geosynthetic systems overlying voids. Geotextiles and Geomembranes, 9. (1990) 11-50. 